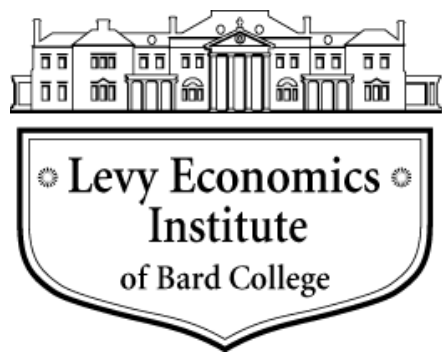

Working Paper No. 936

\title{
Fiscal Reform to Benefit State and Local Governments: The Modern Money Theory Approach
}

\author{
by \\ L. Randall Wray \\ Levy Economics Institute of Bard College \\ and \\ Bard College
}

\section{September 2019}

The Levy Economics Institute Working Paper Collection presents research in progress by Levy Institute scholars and conference participants. The purpose of the series is to disseminate ideas to and elicit comments from academics and professionals.

Levy Economics Institute of Bard College, founded in 1986, is a nonprofit, nonpartisan, independently funded research organization devoted to public service. Through scholarship and economic research it generates viable, effective public policy responses to important economic problems that profoundly affect the quality of life in the United States and abroad.

Levy Economics Institute P.O. Box 5000

Annandale-on-Hudson, NY 12504-5000

http://www.levyinstitute.org

Copyright (C) Levy Economics Institute 2019 All rights reserved

ISSN 1547-366X 


\begin{abstract}
This paper will present the Modern Money Theory approach to government finance. In short, a national government that chooses its own money of account, imposes a tax in that money of account, and issues currency in that money of account cannot face a financial constraint. It can make all payments as they come due. It cannot be forced into insolvency. While this was well understood in the early postwar period, it was gradually "forgotten" as the neoclassical theory of the household budget constraint was applied to government finance. Matters were made worse by the development of "generational accounting" that calculated hundreds of trillions of dollars of government red ink through eternity due to "entitlements." As austerity measures were increasingly adopted at the national level, fiscal responsibility was shifted to state and local governments through "devolution." A "stakeholder" approach to government finance helped fuel white flight to suburbs and produced "doughnut holes" in the cities. To reverse these trends, we need to redevelop our understanding of the fiscal space open to the currency issuer-expanding its responsibility not only for national social spending but also for helping to fund state and local government spending. This is no longer just an academic debate, given the challenges posed by climate change, growing inequality, secular stagnation, and the rise of Trumpism.
\end{abstract}

KEYWORDS: Modern Money Theory; Budget Deficits; State and Local Government Finance; Devolution; Generational Accounting; Stakeholder Approach

JEL CLASSIFICATIONS: E62; H11; H2; H50; H60; H7 


\section{INTRODUCTION: WHAT IS MODERN MONEY THEORY?}

Over the past quarter century, a small group of researchers has developed an approach to macroeconomic theory and policy that has come to be called Modern Money Theory (MMT). ${ }^{1}$ It is based on several traditions that are part of the heterodox approach to economics - that is, followers of J. M. Keynes (Keynesian), Thorstein Veblen (Institutionalist), and Karl Marx (Marxist). In particular, it builds on Keynes's theory of effective demand (from The General Theory [(1936)1964]; independently developed by Marx), Keynes's theory of the nature of money (from his Treatise on Money [(1930)1976], which followed G. F. Knapp's State Theory of Money [1973]), the "monetary theory of production" adopted by Keynes, Veblen, and Marx, Wynne Godley's sectoral balance approach, the endogenous money approach (resurrected in the 1980s by Post Keynesians ${ }^{2}$ ), Abba Lerner's functional finance approach to budgeting, and the financial instability approach of Hyman Minsky. A key policy proposal is the job guarantee, also developed by Minsky. MMT has been devoted to the study of the processes involved when government spends and is particularly critical of orthodox theories and policy recommendations.

MMT argues that budgeting by national sovereign governments that issue their own currency must be analyzed as quite different from budgeting by other economic units such as households, firms, or local governments. Although it is common to apply a household analogy to government spending ("If I ran my household budget like Uncle Sam runs his, I'd go bankrupt"), this is false. Households (and other nonsovereign entities) need to earn income, borrow, or sell assets before spending. They must obtain means of payment to service debt or become insolvent and be forced into bankruptcy. They must "pay back" debts at some point (even at death, creditors can lodge claims against assets to cover debts). They are subject to credit ratings and can be denied loans. And, taken as a whole, nonsovereign entities face various adding-up constraints - the paradox of

\footnotetext{
${ }^{1}$ It is also called Modern Monetary Theory. The first academic monograph introducing the approach was Understanding Modern Money: The key to full employment and price stability, by L. Randall Wray (1998). The three main research institutions that developed MMT are The Center for Full Employment and Price Stability (University of Missouri-Kansas City), The Centre of Full Employment and Equity (University of Newcastle, Australia), and the Levy Economics Institute (Bard College).

${ }^{2}$ See Wray (1990) for a history of the theory of endogenous money.
} 
thrift, problems of insufficiency of aggregate demand, and the "liquidity trap"-long staples of Keynesian macroeconomics. ${ }^{3}$

A sovereign government's finances are quite different. MMT defines currency sovereignty as follows: the sovereign government chooses a money of account and imposes taxes and other obligations (fees, fines), issues currency, and issues its own obligations all in that unit. To maximize policy space, the sovereign does not peg its currency's exchange rate to foreign currency or precious metals and does not issue obligations in foreign currency. The main implications include: 1) the sovereign issues its currency before collecting it in taxes; 2) the sovereign cannot run out of its own currency; 3) the sovereign can always make all payments as they come due in its own currency; 4) the sovereign never needs to borrow its own currency before spending; 5) if the sovereign issues debt in its own currency, it can choose the interest rate it will pay; 6) the sovereign can always financially afford to buy anything that is for sale in its own currency; 7) the sovereign never needs to pay back (retire) its debt; and 8) while there is no affordability constraint, sovereign spending faces real resource constraints and if it spends too much this can cause inflation and possibly affect exchange rates.

Each of these has been examined in detail by MMT scholars, so they will only be briefly summarized here (with some further elaboration later in this paper). From inception, a sovereign cannot collect its own currency in tax payment without first issuing it (since it has a monopoly on issue, the currency cannot come from any other source). While currency can be lent into existence, the most common way to provide it is through spending, as sovereign governments either stamped coins or printed paper notes that were issued as they spent. The currency returned to the government when taxes were paid. Paper notes were often burned on receipt of taxes; coins could be reissued or melted down for a new coinage. As it happens, the American Colonies were among the first big users of paper money in the Western world (Grubb 2017). Every time an act authorized issuing paper notes to be spent, they also imposed what they called a "redemption tax" in a related bill to remove the notes from circulation. It was obvious that no

\footnotetext{
${ }^{3}$ We won't go through these except to give one example. Entities hold liquid assets to sell to obtain means of payment in case of emergencies, but if everyone is trying to sell them the liquidity disappears - so even liquid assets cannot be a source of finance in what Irving Fisher called a "debt deflation."
} 
notes could be collected in taxes until they were spent. There is also a Keynesian logic involved: government spending is an injection into the circular flow that creates income to finance leakages such as saving, imports, and tax payments.

This became obscured after the Fed's creation, shifting to payments made through reserve credits rather than paper notes. But the logic remains the same: reserves cannot be debited for tax payments until they've been created — and the main way that reserves are created is in payments made by the Fed on behalf of the Treasury. Just as the Colonial notes had to exist before they could be "redeemed" in tax payment, we need the means of tax payment (bank reserves) today before taxes can be paid.

Modern governments do not usually spend notes and coins into the economy - they issue currency only to meet the demand, usually when households and businesses convert bank deposits to cash. Rather, payments from and to the treasury are now handled by coordination between private banks and the central bank. The "currency" created by government spending is now central bank reserves - deposits held by private banks at the central bank. Reserves are not included in the usual definition of currency (coins and central bank notes) but for all practical purposes they are perfectly substitutable for currency at par. Further, like paper money, reserves are central bank liabilities that are denominated in the state money of account. Reserves can be created by central bank lending (and by central bank open market purchases), but outside of the recent experiments in quantitative easing $(\mathrm{QE})$, most reserves are created when the treasury spends.

A sovereign government cannot run out of currency - whether it takes the form of coins, paper money, or electronic reserve entries on the central bank's balance sheet. The major central banks demonstrated this fact with QE, as they "keystroked" trillions of dollars, euros, and yen as payment for large-scale asset purchases. Clearly, they could just as easily "keystroke" reserves to banks to allow the treasury to spend. 
Some critics wrongly characterize MMT as a call for turning government spending over to the central banks to "print money" to pay for spending. ${ }^{4}$ This is not correct. Modern procedures already require that central banks credit bank reserves dollar-for-dollar (or yen-for-yen) as the treasury spends. ${ }^{5}$ The treasury issues checks (or increasingly handles payments electronically) and the central bank simply handles clearing - which takes the form of reserve credits to private banks. (The central bank also provides reserves to handle clearing between banks.) At the same time, the central bank debits the treasury's account. From the central bank's perspective, it is clearing accounts, not "creating money," to "pay for" treasury spending. However, unless the central bank is going to start "bouncing" treasury checks, reserves are created dollar-for-dollar with treasury spending.

Until MMT investigated the procedures used, it was not clear how the treasury ensures it has sufficient deposits to be debited by the central bank as the treasury spends. This requires close coordination between the central bank, treasury, and private banks. The treasury obtains credits through tax receipts and bond sales. However, from inception, taxpayers and bond purchasers do not have currency (or reserves, today) to pay taxes or buy bonds unless the government has already provided it. (And, according to the Keynesian logic, households and firms do not have the income to pay taxes or save — buy bonds - unless the government has injected spending.)

Logically, the currency creation through spending comes first. But how can the treasury spend first, since it needs deposits (at the central bank) to avoid bouncing checks? Central banks are generally prohibited from providing overdrafts (although they almost certainly do provide them for at least short periods - the proof is that treasury checks are never returned due to insufficient funds). ${ }^{6}$ Hence, they worked out procedures to ensure that the treasury obtains deposits through sales of bonds that are purchased by banks using either overdrafts or borrowed reserves supplied by the central bank. This serves effectively as an end-run around the "no treasury overdraft" rule.

\footnotetext{
${ }^{4}$ There has recently been an explosion of critics accusing MMT of this policy recommendation-from Fed Chairman Jerome Powell (Cox 2019) to BOJ policy board member Yutaka Harada (Nikkei 2019). See Wray (2019) for a summary and response to some of the critics.

${ }^{5}$ See Wray (1998), Bell (2000), Fullwiler (2011), and Tymoigne (2014) for discussion of modern proceduressummarized also in Wray (2015).

${ }^{6}$ Note that as this is a self-imposed rule, it can be eliminated, which would push the Fed to allow overdrafts (which amounts to the same thing as directly buying bonds from the Treasury).
} 
Once the treasury spends, bank reserves are replenished. If banks don't want to hold bonds, they can be sold to the central bank in secondary markets.

However, banks normally do not want excess reserves created by government spending, so they willingly exchange them for (higher) interest-earning bonds. A key insight of MMT is that bond sales by the treasury or the central bank are functionally equivalent operations. ${ }^{7}$ The conventional view is that treasury sales are a borrowing operation while central bank sales are an open market operation, but in either case the functional impact is to withdraw reserves from banks. Government spending puts reserves into the banking system and the reserves can only leave the system through bond purchases, tax payments, or cash withdrawals from deposits. Cash withdrawals are normally small (with seasonal variability); national government taxes are large but with temporal variation and are usually — for most countries - significantly lower than sovereign government spending. To avoid wide fluctuations of reserves and to deal with net reserve accumulation due to government spending in excess of tax payments as well, the central bank and treasury coordinate bond sales to drain excess reserves. For this reason, MMT sees bond sales as part of monetary policy operations - whether undertaken by the central bank or by the treasury.

Warren Mosler calls bonds an "interest rate maintenance account" held at the central bank to emphasize the functional impact of bond sales. ${ }^{8}$ When a bond is sold, reserves are debited and bond holdings are credited. Because both of these accounts are held at the central bank, this is a transfer from a "checking account" (reserves) to a "savings account" (bonds) to earn more interest. Generally the central bank's overnight interest rate target (the fed funds rate in the United States) is higher than the rate paid on reserves (the Fed paid zero on reserves until recently when it began to pay a "support rate") and it uses sovereign bonds as the instrument to hit the target. The shortest maturity treasury debt serves as the alternative to bank lending of reserves in the overnight market (the fed funds market in the US) and its rate is set by policy.

\footnotetext{
${ }^{7}$ Warren Mosler was the first to understand the full significance of this. He developed his understanding while trading sovereign bonds for his hedge fund. See https://www.scribd.com/document/35432615/Soft-CurrencyEconomics.

${ }^{8}$ See Wray $(1998,88)$.
} 
Rates on other maturities are more complexly determined, although expectations of central bank policy play an important role.

In any event, the central bank can set the rate on any maturity by announcing it stands ready to buy bonds at the announced price equivalent. Note also that the distribution among maturities is a policy decision (referred to as "debt management"). This means both the interest rate on and the composition of government debt is under the control of the government.

While there is a widespread fear that "bond vigilantes" can drive rates up through a "strike," that is unlikely and easily countered by government policy. In the United States, for example, dealer banks are required to place bids for Treasuries sold at auction. Before the auction, the Treasury surveys preferences over maturities to offer what the market wants. The Fed cooperates with banks to ensure they can obtain the reserves they need to buy bonds. ${ }^{9}$ The Treasury maintains special accounts at private banks to temporarily deposit proceeds from bond sales (and from tax receipts), then shifts them to the Fed to meet the projected clearing of government payments. The US Treasury usually faces a demand for securities that exceeds the supply_often by a large margin. The question is not whether the Treasury can sell enough, but rather at what "price" (interest rate), and it often tries to minimize interest expenses by offering the maturities desired. Using current procedures, there is no questioning the ability to pay all promised interest due by "cutting a check" or making electronic payments that will be cleared by the Fed. Furthermore, the Treasury doesn't have to issue any bonds, as rules can be changed to allow overdrafts at the Fed. In that case, the Fed can still maintain a nonzero interest rate target by paying interest on reserves (as it has done since the global financial crisis), rather than using bonds as the interestearning alternative to keep the fed funds rate up in the presence of excess reserves.

Normal Fed operating procedure ensures banks always get the reserves they need to buy bondswhich allows the Treasury to get the deposits it needs in its account at the Fed. Further, as discussed, dealer banks must submit reasonable bids for bond tenders or risk sanctioning and lose the right to deal in the most-coveted financial asset in the world-US Treasury debt.

\footnotetext{
${ }^{9}$ After QE, banks have plenty of reserves so that no further intervention is needed as bonds are sold.
} 
Treasury bond sales are thus quite different from "borrowing" by households, firms, and local and state governments - an issue to which we turn in the next section.

What MMT research has shown is that "affordability" is not a legitimate concern for the sovereign government-it can finance its spending and meet all obligations as they come due. It has substantial control over interest rates and does not face a market full of vigilantes who can strike for higher rates. Even if it did, the government can exert control over its central bank. The Fed, after all, is a "creature of Congress," subject to the Federal Reserve Act (as amended several times over the years). Economists have developed strange arguments defending what is supposed to be an inviolable principle of central bank independence, but in fact in trying times (such as both world wars), the Fed has been placed under the Treasury in pursuit of the public interest to keep rates low as government spending expanded to 50 percent of GDP.

Finally, nothing in this section should be interpreted to mean either that real resource constraints should be ignored, or that too much spending would not cause inflation. Further, increasing government spending can mean that too few real resources are left for the private sector's use. Since the government can always win a bidding war, it needs to be careful to target its spending toward sectors with excess capacity and toward resources that are not fully utilized. Otherwise, it can cause inflationary pressures even before resources are fully employed - particularly if its spending competes in the more advanced sectors that are highly unionized with skilled workers and oligopolized employers with pricing power. This was believed to be a real problem at the end of the 1960s with what was dubbed "Military Keynesianism," which kept aggregate demand high by pumping government spending into the defense and aerospace sectors. Although excessive demand has not been a problem in the United States since then, MMT does not ignore real resource constraints. 


\section{MONEY USERS: STATE AND LOCAL GOVERNMENT AND THE EURO MEMBERS}

When the new euro currency was introduced, MMT analyzed the member-states as if they were US states. ${ }^{10}$ Each was giving up its own currency to join a monetary union by adopting the euro. Similarly, the new US states had joined a monetary union based on the dollar, with each giving up its colonial currency. We analyze states as "users" of the currency, rather than "issuers."

In the case of the United States, the issuer is the national government. The US Constitution gave Congress the sole authority to issue the currency and for much of US history that came under the Treasury's responsibility. The United States was a relative latecomer, as many other nations had long ago created central banks to handle state finances and gradually their central bank notes came to be the predominant form of currency. After the Federal Reserve's creation, its notes, too, eventually replaced Treasury notes (and coins) as the main currency. The Treasury stopped issuing currency to make its payments - coins are issued solely on demand in exchange for Federal Reserve liabilities (notes and reserves), so that they are not "spent into existence." Instead, all Treasury spending and receipts pass through the Fed — which makes or receives all payments from and to the Treasury. As discussed above, most of these payments take the form of credits to bank reserves (bank deposits held at the Fed) — which are perfectly substitutable to Fed notes or Treasury coins. Effectively, most "currency" now takes the form of reserves.

In the case of the euro area, the European Central Bank (ECB) is the issuer of the currency; member-states are users. ${ }^{11}$ Here, however, the distinction is not so clear-cut, as each member nation still has a treasury and a central bank. These central banks make and receive payments for their treasuries. However, neither the member's central bank nor the ECB is supposed to directly "lend" to (that is, purchase debt from) the treasuries. Still, central banks may purchase government bonds in secondary markets (and after the global financial crisis, the ECB also did so) - which effectively provides an end-run around the prohibition (just as it does in the United States). When they do so, they create central bank reserves denominated in the euro. As in the

\footnotetext{
${ }^{10}$ See Bell and Nell (2003) for a collection of chapters outlining the problems with the European Monetary Union (EMU).

${ }^{11}$ Euro notes and coins are issued by member nations; however, the ECB controls the quantities each is allowed to issue. The members retain the seigniorage from minting coins (which is not a very significant source of finance).
} 
case of the United States, these reserves can be exchanged into euro notes and coins on demand. If all payments were to remain within the borders of a member nation, there would be no constraint on the member central bank's ability to "create" euros (purchasing government bonds in secondary markets). By contrast, in the United States, state and local government debts are not bought by the central bank. ${ }^{12}$

A complication arises, however, because euro deposits created within Italy can be transferred to Germany - through both current account deficits and as well capital flows. This then leads to a clearing drain, with a debit against an Italian account and a credit toward a German account. The Target 2 system was created to handle the clearing. The main exporting nations (including, above all, Germany) accumulate large net credits while the importing nations (Spain, Italy, Greece) accumulate large net debits in the Target 2 accounts.

Persistent net flows also occur within the United States; however, US states do not have their own central banks - so the clearing takes place between Federal Reserve District Banks. No one really knows or cares which US states run chronic "current account" imbalances. But in the case of the eurozone, it is easy to identify the current account deficit nations and to link those to the net debits in the Target 2 system and to risk exposures. If, for example, a large net debtor were to default (which could happen on an exit), the net creditors (Germany is by far the largest) could face losses. In the United States it is rather difficult to identify which are the chronic current account deficit states - and the issue of "exit" of a US state was already resolved (in the negative) in the Civil War. The jury is still out on an exit from the EMU. In the United States, the risk is not due to current account imbalances or to danger of an exit, but rather to excessive debt issued by state and local governments (and there is a real risk of default by highly indebted governments).

\footnotetext{
${ }^{12}$ Given that the Fed bought private "troubled assets" and provided the funding for others to do so, it might be able to buy — or at least encourage purchases of - "troubled" state and local government debt. In 1966, banks tried to unload municipal bonds, creating a funding problem for local government. The Fed intervened, sending a letter to member banks announcing it would open the discount window to banks that would help stabilize markets, relieving the pressure - showing the Fed does not have to ignore local government finance (See Minsky 1986, 89-90).

However, the Fed did not rescue the State of New York, Orange County in California, or any number of other state and local governments in their financial crises and it is not likely to do so in the future. This is the difference between operating as a "lender of last resort" when there is a liquidity problem versus providing finance to a government facing fiscal problems.
} 
There are also differences among euro nations regarding how much debt governments have issued (relative to national GDP). If everyone believed that all members are equally creditworthy this wouldn't create systemic problems. However, if some are seen as riskier, then they can face lower credit scores and higher interest rates on government debt. Further, when perceived risk rises, capital flows out of the nation lead to rising Target 2 debits. Wealth holders can easily distinguish between German debt (national and local government debt as well as bank debt) and Greek debt, and can run to the safety of the German government and German bank debt. In the United States, no one cares where a bank might be headquartered, and while there can be a run out of Orange County debt, there is no reason to shun all debt issued by California-based borrowers.

In the United States, virtually all states are required to balance their budgets - at least on their current accounts. They are, however, permitted to borrow for capital projects. Like the euro nations, they vary in their perceived creditworthiness and private credit ratings agencies provide ratings for state and local government debt. States rarely approve budgets that are not balanced, and when their debt is downgraded they react quickly by cutting spending.

There is a large divergence between the debt-to-GDP ratios of eurozone nations and US states (with state government debts measured relative to state GDP). Some eurozone nations have debt ratios of 100 percent or even higher, while US states typically have ratios well-below 20 percent - less than a third of what the Maastricht criteria allow. Again, US states must submit balanced budgets (although ex post budgets can be in register deficit, especially in recessions that usually lead to strong pressure to reduce spending and raise taxes), so state borrowing is typically earmarked to specific projects (such as sports stadiums). Eurozone nations, on the other hand, budget for deficits - and are permitted to do so by Maastricht criteria, which allow deficits of 3 percent of GDP (and most have exceeded this ratio at one time or another).

In sum, in many respects eurozone members enjoy advantages in comparison to US states in that they have greater fiscal policy space, which allows them to plan for deficit spending and to issue debt up to ratios that far exceed what US states are permitted. 
On the other hand, US states have one huge potential advantage. The US federal government's share of GDP is over a fifth, and its deficit is typically around 5 percent of GDP. Mandatory spending is about two-thirds and most of that is Social Security, Medicare, and Medicaid. This is spread among the US states and population in a somewhat progressive manner, while federal taxes are also progressive. That means that net federal spending by state and region tends to flow to lower income populations. Further, with a budget deficit, the federal government is a net source of income to households and firms around the country. Finally, federal government net spending moves countercyclically (because social spending rises in recessions while tax revenues fall). And discretionary spending also tends to be targeted to lower income states and regions. All of this means that there is "redistribution" that favors states with lower income and less favorable economic outcomes.

By contrast, the eurozone's central fiscal authority is the European Parliament, whose budget is less than 1 percent of the eurozone's GDP. Further, that budget is contributed by members, so it is not net spending. While it is distributed on a progressive basis - with low income memberstates receiving relatively larger shares - it is a small drop in the bucket. US transfers are relatively larger, and are not constrained by revenues, as the federal government can and does run large deficits. The differences between the US system and the euro system were quite obvious in the aftermath of the global financial crisis, as US budget deficits grew to a trillion dollars. Uncle Sam bore much of the burden of ramped up social spending (food stamps, unemployment compensation), fiscal stimulus (although limited to two years, it totaled $\$ 800$ billion), and bail-outs of the financial system (the Fed spent and lent \$29 trillion through its alphabet soup of facilities — on top of the Treasury's $\$ 800$ billion of spending on Wall Street). In the eurozone, however, most of the responsibility in all these areas fell to the member nationswhose revenues plummeted in their time of need. The eurozone budget deficits that resulted were met with market reactions (the more indebted nations faced high interest rate spreads) and any help from the ECB or international financial organizations came with strings attached - that typically required austerity. It is not surprising that recovery was more difficult in the euro area.

Still, the US federal government's response was far less than what was needed — which is why the recovery from the global financial crisis was slower than any other postwar recovery. And, 
generally speaking, each subsequent downturn and recovery after the early 1970s has been weaker - so the underlying problem was not unique to the global financial crisis, but has been apparent for a long time. We next turn to the postwar transition of thinking about fiscal constraints of the national government and how that has impacted state and local governments as well as overall economic performance.

\section{THE GOVERNMENT BUDGET CONSTRAINT: FACT AND FANCY}

Economic theory proposes that consumers face a budget constraint such that consumption cannot exceed income plus borrowing capacity - which itself is a function of future income. And all debts must be paid, so lifetime spending equals lifetime income. In the late 1960s, the notion of a budget constraint began to be applied to government, in the form of the government budget constraint (GBC): $\mathrm{G}=\mathrm{T}+\mathrm{dB}+\mathrm{dM}$, where $\mathrm{G}$ stands for government spending (including transfers, interest payments, and purchases), $\mathrm{T}$ is tax revenue, $\mathrm{dB}$ is borrowing (bond issues), and $\mathrm{dM}$ is printing money. Issuing bonds carries two main drawbacks: government borrowing competes with private borrowing, pushing up interest rates (that can "crowd out" private borrowing and thus reduce investment); and bond issue commits government to paying interest plus principal in the future. Printing money is dangerous because it can cause inflation.

Economists developed "sustainability" conditions to ensure budget deficits do not cause government debt ratios to become excessive. Sustainability depends on the relation between the rate of GDP growth and the interest rate: the rate on government debt must be below the GDP growth rate or the debt ratio will grow without limit (Wray 2015, 62-70). The problem is that budget deficits can lower the growth rate (by crowding out private investment - which is presumed to be one of the main sources of growth) and raise interest rates (competing for a scarce supply of loanable funds). Thus, there is a likelihood that interest rates will rise above growth rates, causing the debt ratio to grow, therefore raising spending on interest unsustainably.

In recent years, some orthodox economists have developed a new approach to budgeting, advocating the use of "intergenerational accounting" - that projects government revenue as well 
as spending commitments through an infinite horizon (Kotlikoff and Burns 2005). These two flows are discounted to determine the shortfall—unfunded commitments—-through eternity. Scary numbers - like \$200 trillion of unfunded entitlements due to Social Security and Medicare program shortfalls - can be generated. These are said to be the burden of the debt we are leaving for our grandkids, who will face much higher tax rates to service and ultimately pay down the debt. The presumption is that the government, like a household, must eventually repay all debt. Hence, all deficit spending represents a future tax obligation. In that sense, borrowing is just postponing taxes and not a substitute for tax revenue. Printing money is not a solution, either, as that is just an inflation tax that reduces the purchasing power of money income. Our grandkids will have to pay for our profligacy whether government borrows or prints money.

From the perspective of MMT there are many problems with this. First, the GBC is seen by MMT as an ex post identity, not a constraint. Second, budget deficits place downward pressure on interest rates (not upward). Third, the loanable funds view of finance was already revealed by Keynes to be false. Fourth, a sovereign government that issues its own currency can never be forced to miss any payment as it comes due, so there is no sustainability problem. Fifth, government debt is financial wealth — so leaving debts to our grandkids is a source of wealth, not a burden. Sixth, government debt does not need to be "repaid." Seventh, it is unrealistic to hold the growth rate (g) constant as government spending (including spending on interest) and debt rise without limit - the fiscal stimulus would raise the growth rate above the interest rate and resolve the "unsustainability" problem. Eighth, the interest rate is a policy variable, so it can be held below the growth rate. Though each of these points would require a full paper for a thorough exposition, I will provide a quick explanation for each, with references for further reading.

The so-called GBC is an ex post identity, not a constraint, in the sense that at the end of the accounting period (say, a fiscal year) it will be identically true that government spending over the period will equal taxes received, plus the sum of net bonds and net bank reserves accumulated. As discussed above, government spending always leads to a credit to banking system reserves, dollar for dollar, as the Fed makes payments for the Treasury (the private bank receiving the credit will in turn credit the deposit account of the recipient of the Treasury's spending). Tax 
payments reverse this, resulting in debits to bank reserves. If the government spending flow happened to exactly equal the flow of tax payments, the net impact on bank reserves (and bank accounts of "taxpayers") would be zero. But if spending exceeds taxes, then the deficit means that there have been net credits to banking system reserves. Normally banks do not want to hold excess reserves - and required reserves grow very slowly over the course of a year-so most of the reserves created will be exchanged for Treasury bonds, sold either by the Fed (in the secondary markets, called an open market sale) or by the Treasury (in the new issue market). This is why the identity holds at the end of the period.

Over the course of the year, all three operations (tax receipts, bond sales, and reserve credits) are used on a continuous basis. That is true even if the government will end up with a balanced budget at the end of the year. This is because of the operational procedures adopted by the Treasury and Fed, discussed above, used to handle payments made by the Treasury. These procedures are complicated and they evolve over time. The point is that even if the government is running a budget surplus, it will issue bonds and "print money" (credit reserves) as well over the course of the year! In other words, these are not "optional" ways to "pay for" spending but are simply different parts of the normal procedures to effectuate government spending. All government spending actually takes the form of a credit to bank reserves - this is simultaneous with the spending and there is no alternative in the modern economy. ${ }^{13}$

Since government spending results in reserve credits - and deficits create net reserve creditsbond sales function to drain excess reserves, providing a higher interest-earning alternative. Bond sales keeps excess reserves from driving interest rates down. Deficit spending doesn't cause crowding out; in the absence of bond sales, it would push rates down. In a sense the bond sales are a policy option - if government didn't want to sell them it could adopt slightly different procedures and in that case it would leave the reserves created by government spending in the banking system, which would drive the overnight interest rate down to the central bank's support rate (what it pays on excess reserves). Alternatively, the central bank can buy all bonds in

\footnotetext{
${ }^{13}$ In the old days, the government spent by issuing paper money or coins (usually through the treasury), but today it spends through its central banks.
} 
secondary markets; in this case, treasury payments of interest to the central bank are returned to the treasury (in the United States, Fed profits above a 6 percent return go to the Treasury.)

Government interest payments on bonds held outside the central bank are optional. But whatever interest the government decides it will pay, it will always be able to "afford" to pay it. All payments the government commits to can be paid as discussed above- through credits to bank reserves. Even if the interest rate were above the growth rate, the government can make those payments, as a government never needs to repay its "debt." Even without knowing any theory, it is easy to check to see whether the US government has been paying off its debt since the founding of the nation. Uncle Sam retired the debt only once-during President Jackson's administration. In almost every other year since the founding of the nation, the debt has grown. There were a half-dozen short periods during which some of the debt was retired (the last time was during the Clinton administration), but each was ended with another run-up of debt. Of the seven periods (counting the Jackson episode) of sustained budget surpluses, all but the Clinton surplus was followed by one of our six depressions. The Clinton surplus was followed by the dot-com collapse, recession, and then a speculative bubble that crashed into the global financial crisis.

Why the correlation of budget surpluses and downturns? Maybe it is more than a coincidence. A federal budget surplus means (by identity) that the nongovernment sectors taken as a whole are running deficits. This follows from Godley's sectoral balances: the sum of the balances across the government sector, domestic private sector, and foreign sector is zero. For every sectoral surplus there must be at least one sectoral deficit. If we assume the foreign sector is in balance (the current account is balanced) and then the government runs a surplus, the domestic private sector must run a deficit - and vice versa. Retirement of government debt means (by identity) a reduction of the nongovernment sector's net financial wealth. That is not a good thing. ${ }^{14}$

\footnotetext{
${ }^{14}$ In the case of the United States and other nations that run current account deficits, the implication of a government sector surplus is even more dire: the private sector's deficit equals the sum of the budget surplus and the current account deficit.
} 
This relationship is related to Keynes's argument against the loanable funds view (also related to the view of banks as intermediaries that lend-on the deposits they receive). The fundamental principle behind Keynes's theory is that spending creates income, and it is the spending injection that creates the income that can be leaked. Thus, investment creates saving in the simplest model (with no government or foreign sector); in the expanded model, investment plus the budget deficit plus net exports creates the income that can be saved. It thus makes no sense to argue that savings "finances" investment (and the budget deficit), or even that taxes can "finance" government spending. While the causation can run from saving to investment (or budget deficit) at the individual level, at the aggregate level the logic must go from injection to leakage (every leakage requires an income flow).

This is why postwar Keynesians saw a positive role for government in supporting aggregate demand: it doesn't need income first to spend. As New York Fed Chairman (and Rooseveltian New Dealer) Beardsley Ruml put it in his title in 1946, "Taxes for revenue are obsolete." $\mathrm{He}$ went on to enumerate useful purposes for taxes (reducing sin and inequality, and to remove aggregate demand to fight inflation) but insisted that the war had taught the people and the government that taxes are not needed to finance government spending. Indeed, Keynes's logic taught us that government needs to spend first to generate the income that can be taxed.

While it is true that reserves can come from Fed lending, that is normally a tiny amount in relation to Treasury spending. QE changed that somewhat - the Fed provided several trillion dollars of reserves as it bought US Treasury bonds and mortgage-backed securities. Banks now have sufficient reserves to cover a couple of years' worth of tax payments; however, if the government stopped spending but continued to collect taxes, this would suck so much income and financial wealth out of the taxpaying public that a depression would be inevitable.

Economic growth requires spending injections and modern economies generally need net injections from the government. This is less critical for net exporters, as their spending injection can come from foreigners (think Germany or Taiwan, who rely on exports). Since the days of President Reagan, however, the United States has been running chronic current account deficits - a leakage that now reaches to 6 percent of GDP or more when the United States is 
growing at a reasonable pace. Injections can also come from investment spending (if investment exceeds private sector saving, it is a net injection), however, investment-led growth is not sustainable for a rich, developed country like the United States. This is because, ironically, investment tends to be too productive.

As Ivsey Domar (1948) worried in the early postwar period that investment has two effects: a demand-side (multiplier) effect and a supply-side (capacity) effect. If investment raises capacity more than it raises aggregate demand, we are left with excess capacity that depresses further investment. We then need another source of demand-either government or exports. In the early postwar period the United States relied on both, but over time our allies and our former foes rebuilt and we lost our trade surplus. That meant we had to rely on the government to keep demand high enough to use the plant and equipment we added.

The best research on this "Domar problem" is by economists Harold Vatter and John Walker (1989, 1990, 1997; Wray 2008). In a series of books, they demonstrated that over the course of the whole 20th century, there was a tendency toward secular stagnation that was relieved only when government spending grew faster than GDP, thereby providing the required extra demand. They attributed the serious downturns to periods in which government spending grew more slowly than GDP. During WWII, as well as over the early postwar period, federal government spending grew faster than GDP, producing relatively rapid growth. By around 1960, federal spending reached a plateau, settling in at around a fifth of the economy-growing at the same pace as GDP. However, state and local government spending grew faster than GDP — thanks to the provisioning requirements of the baby boom (hospitals, schools, suburban infrastructure). That lasted until the early 1970s. Since that time, total government spending has remained relatively constant as a percent of GDP — with some exceptions, such as the Reagan defense build-up. Periodic tax cuts have reduced the leakage into taxes, so while government has not been a positive force for growth (only growing in line with GDP), it has sometimes reduced its drag on growth. However - and this is important - because the tax cuts have generally been aimed at the rich or business firms, they do not have much "bang for the buck." 
As Minsky argued, the budget deficits created by tax cuts (as well as by interest payments on government debt run-up since the Reagan tax cuts) are "inefficient"- unlike New Deal and early postwar government spending that boosted both demand and capacity (Minsky 1992; Wray 2018). The consequence has been chronic underperformance of the economy, which depresses investment in a negative self-reinforcing manner, even as a large budget deficit fails to provide the positive stimulus needed to raise growth.

\section{BALANCED BUDGET CONSERVATISM AND THE FISCAL CRISIS OF STATE AND LOCAL GOVERNMENTS}

The early 1970s marked a sharp break from trends of the earlier postwar period as economic growth slowed, as real wages stalled, as union power began a long period of deterioration, as financial crises became increasingly frequent and more severe, and as escaping recessions became more difficult. In the literature, there are contributions to this transition from the "Golden Age" of US capitalism to subpar and even troubling economic performance, but Sid Plotkin and Bill Scheuerman's (1994; henceforth PS) analysis builds on the role played by the changing views of government.

The thesis of PS is that three major trends began in 1973: stagnation, growing inequality, and ballooning federal government debt. These trends replaced the unified political economy of the post-New Deal era with the rise of balanced budget conservatism (BBC) accompanied by tax resistance, dog-eat-dog competition for public spending, government paralysis, and a fiscal squeeze at the state and local government level. Government came to be seen as the problem, not the solution, as Reagan famously put it. And his tax cuts for the rich (which were repeated over the course of the administrations that followed him—right up to President Trump's recent tax "reform") created a chronic budget deficit that allowed government's debt to become the ultimate boogeyman in the way of any serious attempt to deal with post-1973 problems.

The rise of "federalism" shifted responsibilities to state and local levels (devolution), while slower growth of federal spending reduced funding available to states for clean water, sewage 
treatment, garbage, local transit, and public housing. States had to follow suit, devolving much of the costs of such services to local governments. As governments raised sales and property taxes to increase revenues, this generated tax revolts. Competition between governments to attract jobs created tax breaks for corporations, requiring higher taxes on households to make up for the lost revenue (Johnston 2007). The rise of online shopping compounded difficulties as brick and mortar retailers closed and cities lost jobs and tax revenues. Cities slashed services and jobs to cut costs, which together with high taxes helped to fuel the exodus to suburbs - which generally had newer infrastructure and better services—leaving cities destitute.

This played into the hands of BBC philosophy as taxpayers, not citizens, became the basis of government. Suburbanite "stakeholders" pay taxes to fund local government, encouraging the notion that individual taxpayers should get back from government what each pays in taxes. Welfare is seen as a form of theft because recipients receive more from government than they pay. "Money's worth" calculations come to dominate assessments of the viability of the New Deal's most important programs - above all, Social Security. Federal budget deficits were increasingly attributed to "entitlements" going to the undeserving. Generational accounting threatens social programs by proclaiming impossibly large unfunded commitments.

As PS admit, many of the arguments behind federalism sound good: cutting federal bureaucracy, returning power to states, supporting grassroots democracy, and strengthening community. But the reality is ugly: budget constraints are much stricter at the state and local government levels, as discussed above. And since state and local governments are severely restricted in their ability to "net spend" (run deficits), devolution would only work if the federal government provided net revenue (its own deficits) as an injection to state and local economies. However, the rise of BBC and the focus on federal budget deficit reduction (at least as a goal, if not in practice) meant that it was not possible to provide federal funding. Hostility to taxes and "big government" made trickle-down supply-side tax cuts the only palatable policy. The rich got their tax cuts, but only inequality trickled down.

Since state and local tax systems are strongly regressive, shifting responsibility to state and local levels combined with federal supply-side tax cuts increased the overall regressivity of the tax 
system. Slower growth and secular stagnation bring out the worst in local governments and in taxpayers: governments cannot afford services and households do not want more taxes, so bond proposals (schools, infrastructure) are voted down. Public officials play triage, choosing which groups to serve and which to ignore. BBCers promote group conflict among taxpayers and between cities. This plays into the hands of corporations by increasing their political leverage and promoting hostility toward government, as the well-funded push of market ideology promotes the "there is no alternative" (TINA) view. The political fallout includes racism, sexism, white collar versus blue collar, city versus suburb, and ethnic group against ethnic group. As PS put it, federalism makes it difficult to get a majority behind any useful policy, with 80,000 units of government to split up voters along a myriad of class, race, ethnic, and religious lines.

A vicious cycle of federal tax cuts for the rich increases the deficit and fuels demands that "pay fors" must be identified before any new spending bills can be considered. Devolution shifts more responsibility to state and local governments, with less money provided from Washington to cover essential spending. Slow growth creates few jobs, so local governments provide tax giveaways to seduce corporate investment. Fiscal policy is downgraded - in part because of federal deficits and debt growth, but also due to contemporary fads in macroeconomic thinking ("Ricardian equivalents," "growth through fiscal consolidation"). Monetary policy is elevated as the only legitimate stabilizing force, and its focus is on fighting inflation —a problem that disappeared a generation ago.

Even mainstream economists like Larry Summers, Robert Gordon, and Paul Krugman argue that secular stagnation is the "new normal." 15 Meanwhile, the United States is left behind by China, even as it faces the existential threat of climate change that could make earth uninhabitable within a decade. In the United States and abroad, "populist" movements embrace a rise of altright protofascist leaders who pursue policy designed to further fracture the electorate.

\footnotetext{
${ }^{15}$ See Larry Summers's website (http://larrysummers.com/category/secular-stagnation/) for a list of articles in the popular press; see Gordon (2016) for an academic treatment.
} 


\section{FISCAL REFORM IN THE ERA OF TRUMPISM}

As we've discussed, financial affordability is not a problem for the sovereign government, though state and local governments are fiscally constrained. The "dollar currency area" thus has advantages over the eurozone - but only if the federal government uses its policy space wisely. Unfortunately, over the past 45 years or so, the notion that our national government should be "fiscally responsible" has come to dominate. Further, orthodox economists have downgraded the usefulness of fiscal policy and shifted responsibility for macroeconomic performance to the central bank. This means that policy became much more focused on inflation than on employment and economic growth.

When growth is too slow and inflation is low, the Fed lowers its rate target. This will work only on spending that is highly interest sensitive-mostly in asset markets. That is why our business cycle has become so dependent on speculative bubbles in real estate, the stock market, commodities markets, and derivatives that allow betting on financial asset performance. Chronic secular stagnation is relieved by bubbles that inevitably burst. Finally, to the extent that fiscal policy is used, it relies on tax cuts - mostly on higher incomes, on capital gains, and on corporate profits. None of these are very efficient; indeed they tend to reinforce the effects of interest rate cuts, encouraging speculation in assets. Since growth of production and income is not encouraged, tax cuts are accompanied by declining tax revenue that adds fuel to the deficit hawks who worry about the unsustainable growth of government debt.

Trump's Tax Cuts and Jobs Act (TCJA) was just the latest in the long series of "reforms." For our purposes, one of the most important features was that it capped state and local tax deductions at $\$ 10,000$ while raising the standard deduction. The impacts will be greatest in high-tax states, such as New York and California, which have used high income, property, and sales taxes to support more spending. It is estimated that a large majority of taxpayers who used to itemize will now take the standard deduction - potentially paying substantially more in federal taxes. There will be pressure on high-tax states and local governments to "reform" taxes — with a likely increase of the regressivity of state and local taxes (generally, the high-tax states added to the 
progressivity of federal taxes, so if they cut taxes on higher income households, they will become more like the average state that has highly regressive taxes) (Gordon 2018).

While Uncle Sam has the capacity to distribute income to states on a progressive basis, he has never done enough. According to the Urban Institute, in 2012, federal transfers accounted for 23 percent of state and local government revenue, while property taxes, income taxes, and sales taxes contributed 47 percent (Gordon, Auxier, and Iselin 2016). Even with federal funding, about half the states would fall short of raising sufficient revenue to meet their needs even if they raised their own taxes toward the average rates. ${ }^{16}$ In other words, even with greater revenue effort, half the states cannot meet their needs with the sum of their potential revenue plus the current level of help from the federal government.

State and local governments are responsible for a large percentage of the public services a developed country like the United States expects:

\begin{abstract}
The United States is a highly decentralized country. For example, state and local governments fund 85 percent of and deliver all public elementary and secondary education $[\ldots]$. They undertake three-quarters of all government spending on roads, bridges, water treatment facilities, and other infrastructure [...]. They incarcerate 90 percent of prison and jail inmates $[\ldots]$. State and local governments help maintain the social safety net through their own public assistance programs and their participation in joint federal-state programs, such as Medicaid and Temporary Assistance for Needy Families [...]. Gordon, Auxier, and Iselin $(2016,46)$
\end{abstract}

This decentralization has its disadvantages because both fiscal capacity and needs vary considerably across the country. As discussed, the federal government's fiscal capacity is much greater and it can use grants and other transfers to help close the "fiscal gap" (between capacity to raise revenue and funding needs) faced by state and local governments.

\footnotetext{
${ }^{16}$ The methodology used adjusts revenue capacity by the state's economic base — states with low income, sales, and property values have a lower base and will not raise the same amount of revenue for given tax rates; see Gordon, Auxier, and Iselin (2016, 3-5).
} 
In 2014, the federal government distributed $\$ 577$ billion in grants to state and local governments, equivalent to about 17 percent of total federal outlays or 3.3 percent of GDP. The majority (55 percent) of federal grant dollars went to fund health programs, predominantly Medicaid [...]. This allocation represents a departure from the 1950s and 1960s, when transportation and community development programs represented a greater share of the total [...]. Gordon, Auxier, and Iselin $(2016,46)$

However, the federal government has never really provided funding at the necessary level to tackle state and local fiscal gaps and has never provided much general purpose revenue - even at its peak, "general revenue sharing" only amounted to 1.5 percent of federal spending (between 1976-82) (Gordon, Auxier, and Iselin 2016, 47). Since the end of the 1970s, with the exception of the Medicaid program, federal transfers to states have not been well-targeted to make up for fiscal gaps.

Moving forward, true "reform" would involve more funding flowing from Washington to state and local governments. While there are many ways to go about doing this, we will suggest four main programs, three of which are closely tied to the Levy Economic Institute's Green New Deal (GND) proposal: ${ }^{17}$ healthcare for all through a single-payer program formulated along the lines of the traditional Medicare program; a universal job guarantee program that pays $\$ 15$ per hour with basic benefits, including childcare; a national infrastructure program to "green" the economy and bring it into the 21 st century; and general revenue sharing and/or block grants for states to replace revenue lost by phasing out regressive taxes.

As the first three are part of the Levy GND program, we won't go into details here except to summarize impacts on state budgets. The single payer "Medicare for all" (M4A) program would eliminate most federal and state spending on Medicaid (whether there would still be a role for Medicaid to play would depend on the range of care services covered, for example: Would it include long-term care in nursing homes?), as well as most state and local government spending on healthcare for their employees and retirees (state and local governments might want to offer extra benefits beyond what M4A provides). Clearly this reform would provide huge savings for state and local governments.

${ }^{17}$ We will only briefly summarize the proposal here; for more details, see Nersisyan and Wray (2019). 
The Levy Institute (Wray et al. 2018) has simulated the effects of a universal job guarantee program that would directly employ 15 million workers (while creating an additional 4 million private sector workers). It would raise GDP and national income by about a half a trillion dollars and boost state budget revenues by $\$ 53$ billion. The job guarantee projects would be undertaken by nonprofits and state and local governments, with the wages and benefits paid by the federal government. Projects would be largely devoted to care services: care for the environment, communities, and people. The intent is to supplement, not replace, what state and local governments already do, providing a pool of employed labor to undertake new projects. The simulation assumes the federal government would also provide funding equal to 25 percent of the job guarantee wage bill to cover materials and administration costs. It is possible that state and local governments would need to provide some additional funding for supervision, training, materials, and administration, but most program costs would be covered by the national federal government.

The job guarantee projects could include "greening" projects, but probably would not include any major infrastructure projects due to prevailing wage laws and the Davis-Bacon Act (which would require higher wages). However, the Levy GND proposal includes substantial new federal spending to mitigate climate change - greening projects (to move to carbon-neutral energy sources, etc.) alone would amount to 5 percent of GDP annually; other public infrastructure costs have not been estimated but would likely amount to several percent of GDP per year. All of this spending would help to revitalize local economies and to provide 21 st century infrastructure.

Finally, we need a policy of federal funding for state and local governments that would reduce the use of regressive taxes (if not eliminate them). This could be done on a voluntary basis, with built-in incentives so that revenue lost from the reduction of regressive taxes would be more than offset by federal funding. Total funding made available should be linked to the fiscal effort made and as well to needs. Hence, three factors would be important determinants of the funding provided: fiscal effort, need, and willingness to move from regressive to progressive taxes. Obviously this will require more research and thought to create a workable formula. 
The most important point is that the federal government can and should take more responsibility for providing the funding for state and local government spending. The first step is to understand that the fiscal capacity of the federal government is not determined by its inherited debt ratio, by its tax revenue, or by bond vigilantes. This does not mean that government can spend without limit - spending should be limited by the quantity of resources that can and should be devoted to the pursuit of the public purpose. Exactly what is the public purpose and what should be left for the pursuit of private interest will remain a politically contentious issue. But we can first ensure that all of today's resources are fully mobilized. If used wisely, there will be more resources available for the future. Our most valuable resource—-labor-cannot be simply stored for later use; for the most part, whatever we do not use now is lost forever, and its future potential can even be degraded by idleness today. 


\section{REFERENCES}

Bell, S. 2000. "Do taxes and bonds finance government spending?" Journal of Economic Issues 34(3): 603-20.

- 2002. "Convergence Going In, Divergence Coming Out: Default Risk Premiums and the Prospects for Stabilization in the Eurozone." CFEPS Working Paper No. 24. Kansas City, MO: Center for Full Employment and Price Stability.

Bell, S., and E. Nell. 2003. The State, the Market and the Euro: Chartalism versus metallism in the theory of money. Cheltenham, UK: Edward Elgar.

Cox, J. 2019. "Powell says economic theory of unlimited borrowing supported by Ocasio-Cortez is just 'wrong." CNBC, February 26. Available at: https://www.cnbc.com/2019/02/26/fed-chief-says-economic-theory-of-unlimitedborrowing-supported-by-ocasio-cortez-is-just-wrong.html

Domar, E. D. 1948. "The Problem of Capital Accumulation." The American Economic Review 38(5): 777-94.

Fullwiler, S. 2011. "Treasury Debt Operations: An analysis integrating social fabric matrix and social accounting matrix methodologies." Unpublished paper. Available at: http:papers.ssrn.com/sol3/papers.cfm?abstract_id=1825303.

Garber, P. M. 1998. "Notes on the Role of TARGET in a Stage III Crisis.” NBER Working Paper 6619. Cambridge, MA: National Bureau of Economic Research.

Godley, W. 1997. "Curried Emu—The Meal that Fails to Nourish.” Observer (London), August 31 .

Gordon, R. J. 2016. The Rise and Fall of American Growth: The U.S. Standard of Living since the Civil War. Princeton, NJ: Princeton University Press.

Gordon, T. 2018. "The Price We Pay for Capping the SALT Deduction.” Tax Vox blog, February 15.

Gordon, T., R. Auxier, and J. Iselin. 2016. “Assessing Fiscal Capacities of States: A Representative Revenue System-Representative Expenditure System Approach, Fiscal Year 2012." Taxes and Budget Research Report. Washington, DC: Urban Institute.

Grubb, F. 2017. “Colonial Virginia's Paper Money Regime, 1755-1774: A Forensic Accounting Reconstruction of the Data." Historical Methods 50(2): 96-112.

Johnston, D. C. 2007. Free Lunch: How the Wealthiest Americans Enrich Themselves at Government Expense and Stick You With The Bill. London: Penguin. 
Keynes, J. M. (1936)1964. The General Theory of Employment, Interest and Money. New York: Harcourt, Brace, Jovanovich.

—. (1930)1976. A Treatise on Money, Volumes I and II. New York: Harcourt, Brace \& Co.

Knapp, G. F. 1973. The State Theory of Money. Clifton, NJ: Augustus M. Kelley.

Kotlikoff, L., and S. Burns. 2005. The Coming Generational Storm: What you need to know about America's economic future. Cambridge, MA: The MIT Press.

Lerner, A. P. 1943. "Functional finance and the federal debt." Social Research 10(1) 38-51.

Minsky, H. P. 1992. "Reconstituting the United States' Financial Structure: Some Fundamental Issues.” Levy Institute Working Paper No. 69. Annandale-on-Hudson, NY: Levy Economics Institute of Bard College.

. 1986. Stabilizing an Unstable Economy. New Haven, CT: Yale University Press.

- 2013. Ending Poverty: Jobs not Welfare. Annandale-on-Hudson, NY: Levy Economics Institute of Bard College.

Nersisyan, Y., and L. R. Wray. 2019. "How to Pay for the Green New Deal." Levy Institute Working Paper No. 931. Annandale-on-Hudson, NY: Levy Economics Institute of Bard College.

Nikkei. 2019. "Growing Modern Monetary Theory debate rattles Japan officials.” Nikkei Asian Review, May 28. Available at: https://asia.nikkei.com/Economy/Growing-ModernMonetary-Theory-debate-rattles-Japan-officials

Plotkin, S., and W. E. Scheuerman. 1994. Private Interest, Public Spending: balanced budget conservatism and the fiscal crisis. Montreal, New York, and London: Black Rose Books.

Ruml, B. 1946. “Taxes for Revenue are Obsolete.” American Affairs 8(1): 35-39.

Tymoigne, E. 2014. "Modern Money Theory and the Interrelation between the Treasury and the Central Bank: The Case of the United States." Journal of Economic Issues 48(3): 641-62.

Vatter, H. G., and J. F. Walker. 1989. "Why has the United States operated below potential since World War II?” Journal of Post Keynesian Economics 11(3): 327-46.

. 1990. The Inevitability of Government Growth. New York: Columbia University Press.

—. 1997. The Rise of Big Government in the United States. Armonk, NY: M.E. Sharpe.

Veblen, T. (1904)1958. The Theory of Business Enterprise. New York: A Mentor Book. 
Wray, L. R. 1990. Money and Credit in Capitalist Economies: The Endogenous Money Approach. Aldershot, UK: Edward Elgar.

-1998. Understanding Modern Money: The key to full employment and price stability. Northampton, MA: Edward Elgar.

—. 2008. "Demand Constraints and Big Government." Journal of Economic Issues 42(1): $153-73$.

- 2015. Modern Money Theory: A primer on macroeconomics for sovereign monetary systems. New York: Palgrave Macmillan.

- 2018. "Functional Finance: A Comparison of the Evolution of the Positions of Hyman Minsky and Abba Lerner." Levy Institute Working Paper No. 900. Annandale-onHudson, NY: Levy Economics Institute of Bard College.

—. 2019. "MMT Responds to Brad DeLong's Challenge.” New Economic Perspectives blog, March 12. Available at: http://neweconomicperspectives.org/2019/03/mmtresponds-to-brad-delongs-challenge.html

Wray, L. R., F. Dantas, S. Fullwiler, P. R. Tcherneva, and S. A. Kelton. 2018. "Public Service Employment: A Path to Full Employment.” Research Report, April. Annandale-onHudson, NY: Levy Economics Institute of Bard College. 